Florida International University FIU Digital Commons

$12-1-2015$

\title{
Chloroplasts morphology investigation with diverse microscopy approaches and inter-specific variation in Laurencia species (Rhodophyta)
}

Wladimir Costa Paradas

Instituto de Pesquisas Jardim Botânico do Rio de Janeiro

Leonardo Rodrigues Andrade

Universidade Federal do Rio de Janeiro

Leonardo Tavares Salgado

Instituto de Pesquisas Jardim Botânico do Rio de Janeiro

Ligia Collado-Vides

Department of Biological Sciences and Southeast Environmental Research Center, Florida International University, colladol@fiu.edu

Renato Crespo Pereira

niversidade Federal Fluminense

See next page for additional authors

Follow this and additional works at: https://digitalcommons.fiu.edu/cas_bio

\section{Recommended Citation}

Paradas, Wladimir Costa; Andrade, Leonardo Rodrigues; Salgado, Leonardo Tavares; Collado-Vides, Ligia; Pereira, Renato Crespo; and Amado-Filho, Gilberto Menezes, "Chloroplasts morphology investigation with diverse microscopy approaches and inter-specific variation in Laurencia species (Rhodophyta)" (2015). Department of Biological Sciences. 74.

https://digitalcommons.fiu.edu/cas_bio/74 
Authors

Wladimir Costa Paradas, Leonardo Rodrigues Andrade, Leonardo Tavares Salgado, Ligia Collado-Vides, Renato Crespo Pereira, and Gilberto Menezes Amado-Filho 


\title{
Chloroplasts morphology investigation with diverse microscopy approaches and inter-specific variation in Laurencia species (Rhodophyta)
}

\author{
Wladimir Costa Paradas ${ }^{1}$, Leonardo Rodrigues Andrade ${ }^{2}$, Leonardo Tavares Salgado ${ }^{1}$, \\ Ligia Collado-Vides ${ }^{3}$, Renato Crespo Pereira ${ }^{4}$ and Gilberto Menezes Amado-Filho,*
}

${ }^{1}$ Instituto de Pesquisas Jardim Botânico do Rio de Janeiro (IPJBRJ), Rio de Janeiro, RJ 22460-030, Brazil

${ }^{2}$ Laboratório de Biomineralização, Instituto de Ciências Biomédicas, CCS, Universidade Federal do Rio de Janeiro, Rio de Janeiro, RJ 21941-902, Brazil

${ }^{3}$ Department of Biological Sciences and Southeast Environmental Research Center, Florida International University, Miami, FL 33199, USA

${ }^{4}$ Departamento de Biologia Marinha, Universidade Federal Fluminense, Niterói, RJ 24001-970, Brazil

The present study described with different microscopy approaches chloroplasts lobes in Laurencia sensu latu (Rhodophyta) species and found inter-specific differences among them. Chloroplasts were investigated using confocal laser scanning microscopy (LSM), transmission electron microscopy (TEM) and high resolution scanning electron microscopy (HRSEM). Using and TEM and HRSEM images we distinguished chloroplasts with lobes than chloroplasts without lobes in Yuzurua poiteaui var. gemmifera (Harvey) M. J. Wynne and Laurencia dendroidea J. Agardh cortical cells. The LSM images showed chloroplasts lobes (CLs) with different morphologies, varying from thicker and longer undulated projections in Y. poiteaui var. and L. dendroidea to very small and thin tubules as in Laurencia translucida Fujii \& Cordeiro-Marino. The diameter and length of CLs from Y. poiteaui var. and L. dendroidea were significantly higher than L. translucida CLs $(\mathrm{p}<0.01)$. Based on LSM observations, we suggest that lobes morphology has a taxonomic validity only to characterize L. translucida species.

Key Words: chloroplasts lobes; confocal laser scanning microscopy; Laurencia dendroidea; Laurencia translucida; morphometry; transmission electron microscopy; Yuzurua poiteaui var. gemmifera

\section{INTRODUCTION}

Chloroplast lobes (CLs) are chloroplasts extensions filled with thylakoid membranes, found in polymorphic and dividing chloroplasts of plant and algae (Barnabas 1982, Sarafis 1998, Wilson et al. 2002, Škaloud et al. 2005, Proctor et al. 2007, Tischendorf et al. 2007, Schottkowski et al. 2012). Although CLs were already described in dif- ferent red algae classes such as Cyanidiophyceae (Tischendorf et al. 2007), Bangiophyceae (Bisalputra and Bailey 1973, Cole and Sheath 1980) and Florideophyceae (Young 1978), their ultrastructure remains poorly know in red algae.

Recent morphology studies in red algae addressed the
(9) This is an Open Access article distributed under the terms of the Creative Commons Attribution Non-Commercial License (http://creativecommons.org/licenses/by-nc/3.0/) which permits unrestricted non-commercial use, distribution, and reproduction in any medium, provided the original work is properly cited.
Received August 19, 2015, Accepted November 9, 2015

* Corresponding Author

E-mail: gfilho@jbrj.gov.br

Tel: +55-21-3204-2150, Fax: +55-21-2304-2071 
cellular responses of chloroplasts (e.g., CLs) exposed to different environmental conditions (Bouzon et al. 2012, Schmidt et al. 2012, Gouveia et al. 2013, Dos Santos et al. 2014). On other hand, ultrastructure of CLs have been recognized as an important tool in red algae taxonomy and phylogeny (Kikuchi and Shin 2005, Müller et al. 2010, Kushibiki et al. 2012), even this characteristic being quite variable (Cole and Sheath 1980, Wilson et al. 2002, Gillard et al. 2008). Thus, the study of CLs by using different microscopy approaches should improve the basic knowledge about this organelle in different red macroalgae species.

The Laurencia complex (Florideophyceae) contains 208 species accepted taxonomically being separated into seven genera: Laurencia, Osmundea, Chondrophycus, Palisada, Yuzurua, Laurenciella, and Coronaphycus (Metti et al. 2015). Laurencia species have been reported worldwide, occurring from intertidal to subtidal zones up to $65 \mathrm{~m}$ in depth and from temperate to tropical shores (Fujii et al. 2011).

Many species from Laurencia complex have no defined taxonomic boundaries and present extensive morphological plasticity, making their taxonomic delimitation difficult (Fujii et al. 2011). Morphological characters (Saito 1967, Nam et al. 1994, Garbary and Harper 1998, Nam 1999, 2006) and molecular markers (Nam et al. 2000, Abe et al. 2006, Fujii et al. 2006, Díaz-Larrea et al. 2007, Gil-Rodríguez et al. 2009, Martin-Lescanne et al. 2010) have been used for delimiting taxa, but until know no study performed the cellular characterization of CLs in Laurencia species.

Laurencia species are prolific synthesizers of halogenated terpenes and acetogenins (Fujii et al. 2011). These metabolites play important ecological roles, but also many biotechnological applications were described for them, e.g., antifouling paint (Da Gama et al. 2003). In addition, the genomic information of $L$. dendroidea species had advanced in consequence of a broad transcriptomic analysis, which unveiled many genes responsible for the synthesis of terpenoid compounds (De Oliveira et al. 2012, 2015).

It is well documented that Laurencia species, which stores halogenated metabolites inside storage structures as corps en cerise (CC) (Feldmann and Feldmann 1950), produces a higher quantity of halogenated metabolites than species without CC (Suzuki et al. 1987). However, studies with a cellular approach are scarce. Until now, among all species from Laurencia complex, only two have been extensively investigated in cellular, chemical and ecological levels, Laurencia dendroidea J. Agardh (Sudatti et al. 2006, Salgado et al. 2008, Paradas et al. 2010) and Laurencia translucida Fujii \& Cordeiro-Marino (Paradas 2013).

Concerning major advances in cell biology, it was shown that $L$. dendroidea transports halogenated metabolites from CC to thallus surface in response to epiphytic bacteria through vesicle traffic (Paradas et al. 2010). In addition, Reis et al. (2013) showed that cytoskeleton elements have a central role in this $L$. dendroidea defensive system. In this case, it was shown that microfilaments transport the halogenated metabolites within vesicles by membranous tubular connections from CC to the cell periphery, while microtubules are involved in the vesicle positioning along cell periphery (Reis et al. 2013).

In this way, the aim of this work was to perform a fine characterization of the CLs in three species of Laurencia sensu latu (Yuzurua poiteaui var. Harvey M. J. Wynne, $L$. dendroidea, and L. translucida) using confocal laser scanning microscopy (LSM), conventional transmission electron microscopy (TEM), and high resolution scanning electron microscopy (HRSEM).

\section{MATERIALS AND METHODS}

\section{Algal sampling}

Y. poiteaui var. gametophytes were collected by selfcontained underwater breathing apparatus (SCUBA) in the subtidal (December 2011) of Sprigger Bank, Florida Keys (Florida State, USA; $22^{\circ} 45^{\prime} 42.17^{\prime \prime}$ N, 41 ${ }^{\circ} 52^{\prime} 29.25^{\prime \prime}$ W, 2 m depth, WC Paradas, Y. poiteaui var., RB 630073), while gametophytes of L. translucida and L. dendroidea were harvested from the lower intertidal zone at Rasa Beach (Armação dos Búzios, Rio de Janeiro State, Brazil; 22 $43^{\circ} 58^{\prime \prime} \mathrm{S}$, $41^{\circ} 57^{\prime} 25^{\prime \prime}$ W, rocky shore, WC Paradas, Laurencia translucida RB 629414 and L. dendroidea RB 629412) in January of 2012. No specific permit was required for collection of $Y$. poiteaui var., $L$. dendroidea, and $L$. translucida samples in the studied areas. The harvesting areas are public and the algae are not endangered or protected species. These samples were transported alive to the laboratory in local seawater inside thermal containers.

\section{LSM}

Live algae (Y. poiteaui var., L. dendroidea, and L. translucida) were sectioned longitudinally with a razor blade, placed on glass cell chambers covered with coverslips (Corning Inc., Corning, NY, USA), and then immediately 
observed under a Leica TCS SPE AOBS (Leica Microsystems Company, Wetzlar, Hesse, Germany) or a Zeiss 710 LSM (Zeiss Company, Oberkochen, Baden-Württemberg, Germany). We took advantage of the natural property of light absorption and the auto-fluorescence of chlorophyll $a$ to obtain images of chloroplasts and their lobes. Imaging was performed using the violet laser (at $405 \mathrm{~nm}$ ) as the excitation wavelength and the red light $(650-750 \mathrm{~nm})$ as emission. Images were collected with $2.048 \times 2.048$ pixels of resolution using LASER at low potency and faster scanning speed to avoid pigment bleach during the acquisition.

\section{Morphometry of CLs}

The diameter and length of CLs from Y. poiteaui var. L. dendroidea, and L. translucida vegetative cortical cells were measured using LSM images and ImageJ software (Abramoff et al. 2004). The data were evaluated for similarity of variance using Levene's test (ANOVA). One-factor analyses of variance (ANOVA) were performed to compare the mean values of CLs diameter and length randomly from 6 cells from different gametophytes $(n=10$ per cell, total $\mathrm{n}=60$ ) by using STATISCA ver. 8.0 software (Statsoft Inc., Tulsa, OK, USA). A Tukey post-hoc test was employed to compare the diameter and length of Laurencia species CLs after a significant ANOVA test. Differences were considered significant when $\mathrm{p}<0.05$.

\section{Sample preparation for TEM}

For ultrastructural characterization of CLs, Y. poiteaui var. individuals were fixed with $4 \%$ formaldehyde and $2.5 \%$ glutaraldehyde in a seawater containing $25 \mathrm{mM}$ piperazine-N,N'-bis 2-ethanesulfonic acid (PIPES) and $25 \mathrm{mM}$ 4-2-hydroxyethyl-1-piperazineethanesulfonic acid (HEPES) ( $\mathrm{pH}$ 7.4) for $2 \mathrm{~h}$ at room temperature (all reagents were obtained from Sigma-Aldrich, St. Louis, MO, USA) and washed in the same buffer $(3 \times 10 \mathrm{~min})$. Afterwards, the samples were submitted to increasing series of glycerol $(10,20$, and $30 \%)$ in buffered seawater for $12 \mathrm{~h}$ each concentration. Thereafter, the samples were transferred to flat aluminum supports and fast-plunged into liquid freon 22 cooled with liquid $\mathrm{N}_{2}$. Frozen fragments of $Y$. poiteaui var. were freeze-substituted with $1.5 \%$ uranyl acetate in methanol at $-90^{\circ} \mathrm{C}$ for $24 \mathrm{~h}$ using a freezesubstitution machine (Leica Microsystems Company) (Kachar and Reese 1988). Samples were embedded in acrylic resin (Lowicryl) and polymerized under UV light for 2 days at $-45^{\circ} \mathrm{C}$.
Ultrathin sections ( $50 \mathrm{~nm}$ ) were obtained in a ReichertJung ultramicrotome (Leica Microsystems Company), collected on copper grids (300 mesh) (Electron Microscopy Sciences, Hatfield, PA, USA) and observed in a JEOL 1010 EX TEM microscope operated at $80 \mathrm{kV}$ (Jeol Company, Tokyo, Japan).

\section{Sample preparation for HRSEM}

Fragments of thalli from L. dendroidea and Y. poiteaui var. were cut with a razor blade in random directions to expose the cytoplasm and immediately fixed with $4 \%$ formaldehyde, $2.5 \%$ glutaraldehyde, $25 \mathrm{mM}$ PIPES, 25 mM HEPES, $140 \mathrm{mM} \mathrm{NaCl}, 2 \mathrm{mM} \mathrm{CaCl}, 1 \mathrm{mM} \mathrm{MgCl}_{2}$, $1 \mu \mathrm{M}$ taxol, and $2 \mu \mathrm{M}$ phalloidin in distilled water $(\mathrm{pH}$ 7.4) for $30 \mathrm{~min}$ at room temperature (all reagents were obtained from Sigma-Aldrich). The post-fixation step was performed following the osmium tetroxide-thiocarbohydrazide-osmium tetroxide (OTOTO) method, as follows: alternated bathes of $1 \%$ osmium tetroxide and $1 \%$ tannic acid aqueous solutions for $1 \mathrm{~h}$ each with washes in between (Kachar et al. 2000). Then, the samples were dehydrated with an ethanol series (30,50, 70, and $100 \%)$, critical-point dried and mounted on aluminum holders coated with carbon conductive tape. The thalli of $L$. dendroidea and Y. poiteaui var. was physically fractured accordingly previous works (Paradas et al. 2010, 2015). Then, the samples were coated with a thin platinum layer $(6 \mathrm{~nm})$ using a Balzers BAF 300 freeze-fracture machine (Oerlikon, Balzers, Liechtenstein). Images were captured in a field emission gun SEM Hitachi 4800 (Hitachi Ltd., Tokyo, Japan; at $5 \mathrm{kV}$, spot-size $=2 \mathrm{~nm}$, and working distance $=2 \mathrm{~mm}$ ).

\section{RESULTS}

LSM images of $Y$. poiteaui var. cortical cells revealed an auto-fluorescence pattern $(\sim 700 \mathrm{~nm})$ related to chlorophyll $a$ signal in chloroplasts adjacent to the plasma membrane (Fig. 1A). No other organelle presented red auto-fluorescence. The chloroplasts observed exhibited CLs as tubular projections that connected series of chloroplasts (Fig. 1A, inset). The average diameter and length of the tubules were $0.47 \pm 0.35 \mu \mathrm{m}$ and $4.52 \pm 4.30 \mu \mathrm{m}$, respectively (Table 1).

Laurencia dendroidea HRSEM images of cortical cells showed numerous chloroplasts and smaller spherical mitochondria adjacent to the plasma membrane (Fig. 1B). The chloroplasts exhibited elongated shapes with lobes 

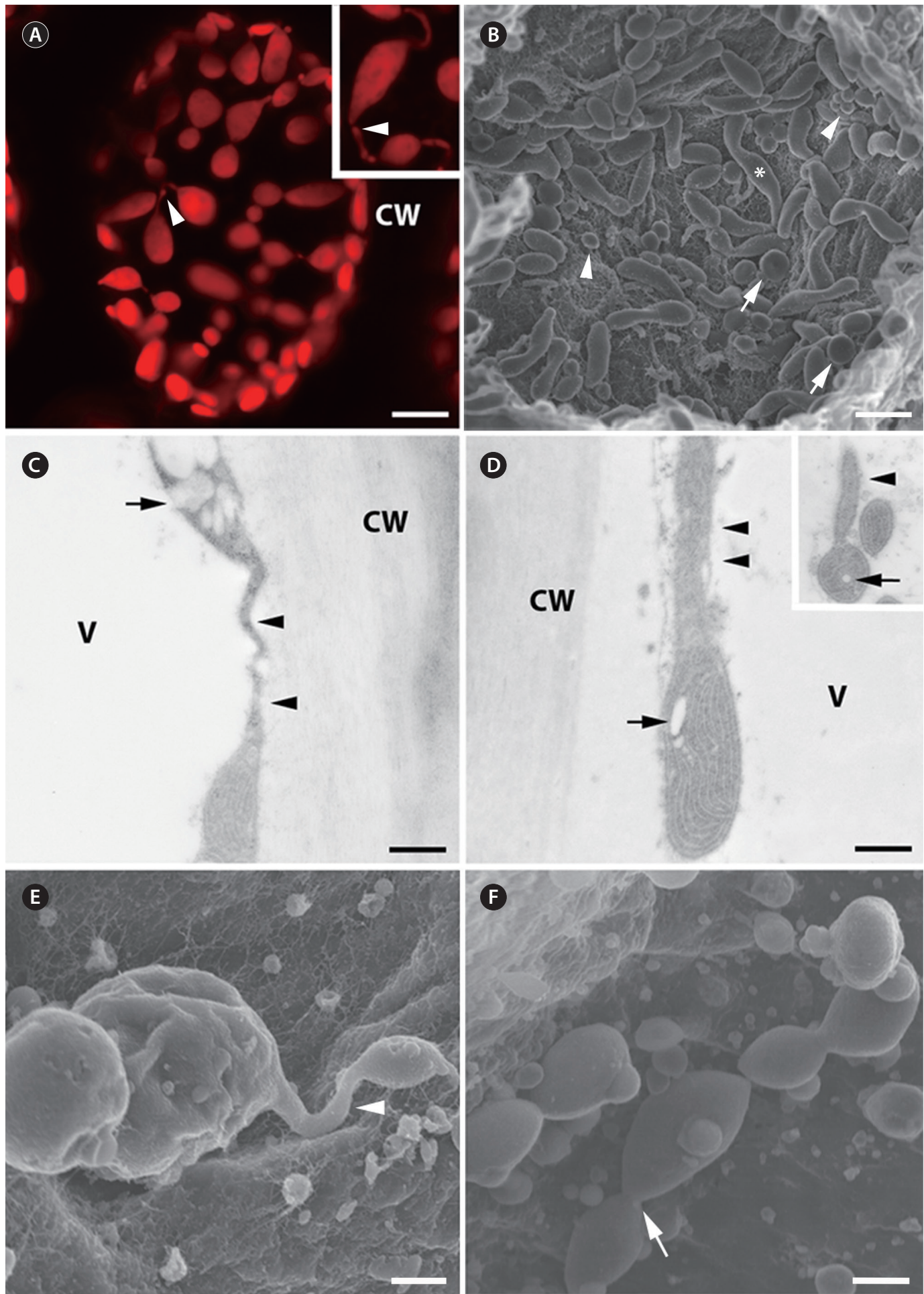

Fig. 1. Choroplast lobes (CLs) in Laurencia cortical cells. (A) A confocal laser scanning microscopy mage of Yuzurua poiteaui var. showing the auto-fluorescence of chloroplasts. The insert image shows the detail of chloroplasts connected by tubular projections (arrowheads). CW, cell wall. (B) A high resolution scanning electron microscopy (HRSEM) image of $L$. dendroidea elongated lobed (asterisk) and discoid chloroplasts (arrows). Arrowheads are ponting to mitochondria. (C) A transmission electron microscopy (TEM) image of $Y$. poiteaui var. showing a chloroplast without lobes and thin cytoplasm projection (arrowheads). Arrow indicates starch grains. V, vacuole. (D) A TEM image of Y. poiteaui var. showing the CLs with thylakoids membranes (arrowheads) growing from small plastids. Arrows are pointing to chloroplasts inclusions between thylakoids membranes. (E) A HRSEM image of $Y$. poiteaui var. showing the CL (arrowhead). (F) Image of the Y. poiteaui var. cytoplasm with attached chloroplasts (arrow). Scale bars represent: A, $4 \mu \mathrm{m} ; \mathrm{B}, 5 \mu \mathrm{m} ; \mathrm{C}, 2 \mu \mathrm{m} ; \mathrm{D}, 1.5 \mu \mathrm{m} ; \mathrm{E}, 750 \mathrm{~nm} ; \mathrm{F}, 850 \mathrm{~nm}$. 
or discoid shapes without lobes (Fig. 1B). In the same way, TEM images of Y. poiteaui var. cortical cells were capable to differentiate chloroplast without lobes (Fig. 1C) from chloroplasts with lobes (Fig. 1D, inset). HRSEM of $Y$. poiteaui var. cortical cells showed a different perspective of the chloroplast tubular lobes as described early by LSM and TEM (Fig. 1E). It is clear that the projections are part of the chloroplast per se, and not part of the cytoplasm or other organelle. Often, we observed chloroplasts fused laterally as shown in Fig. 1F.

Three-dimensional reconstructions of $Y$. poiteaui var. whole cells performed by LSM revealed that, in many instances, chloroplasts were fused laterally and formed a row of several chloroplasts giving a unity aspect (Fig. 2A). Closer look at the L. dendroidea chloroplast by LSM showed the details of CLs with long projections connecting the plastids (Fig. 2B). The CLs exhibited different morphologies, varying from thicker and longer undulated projections as in Y. poiteaui var. (Fig. 1A, inset) and L. dendroidea (Fig. 2B-D) to very small and thin tubules as in L. translucida (Fig. 3A-D). The diameter and length of CLs from Y. poiteaui var. and $L$. dendroidea were significantly higher than L. translucida CLs ( $<<0.01)$. Since chlorophyll is specifically found into the plastids, all red signals from LSM are assumed to come from chloroplasts.

\section{DISCUSSION}

The goal of the present study was describe CLs with different microscopy approaches in Laurencia sensu latu (Rhodophyta) species and find inter-specific differences among them. CLs were observed by HRSEM, specifically in Y. poiteaui var. and L. dendroidea cortical cells. The HRSEM images of both algae cortical cells differentiated CLs profile from only associated chloroplasts. The CLs

Table 1. Morphometric analyses of Laurencia species CLs $(n=60)$

\begin{tabular}{ccc}
\hline \multirow{2}{*}{ Species } & \multicolumn{2}{c}{ Lobes } \\
\cline { 2 - 3 } & Diameter $(\mu \mathrm{m})$ & Length $(\mu \mathrm{m})$ \\
\hline Yuzurua poiteaui var. & 0.47 & 4.52 \\
SD & 0.10 & 1.0 \\
L. dendroidea & 0.47 & 6.6 \\
SD & 0.05 & 2.0 \\
L. translucida & $0.15^{\mathrm{a}}$ & $2.3^{\mathrm{a}}$ \\
SD & 0.05 & 0.2 \\
\hline
\end{tabular}

$\mathrm{SD}$, standard deviation.

${ }^{\mathrm{a}}$ Significant when $<0.01(a=5 \%)$ ANOVA / Tukey Test. were also visualized in the Y. poiteaui var. cortical cells by LSM and TEM, while in L. dendroidea and L. translucida cortical cells by LSM.

Recent studies showed the importance of red algae CLs for species delimitation (Müller et al. 2010, Kushibiki et al. 2012). For example, Kushibiki et al. (2012), based on TEM and LSM images showed that Bulboplastis apyrenoidosa (Rhodellophyceae) could be distinguished from Rhodospora sordida (Rhodellophyceae) by the shape of its chloroplasts, while Bulboplastis has a single lobed chloroplast, Rhodospora sordida has multiple discoid chloroplasts (Geitler 1927, Johansen et al. 2005). Ultrastructural of CLs were also used by Yoon et al. (2006) to proposed three monophyletic classes: Rhodellophyceae, Porphyridiophyceae, and Stylonematophyceae.

Škaloud et al. (2005) based on LSM images found differences among CLs morphology in different ontogeny phases from Dictyochloropsis species (D. splendida, D. reticulate, and D. symbiontica) (Trebouxiophyceae). Laser scanning confocal microscopy has also been repeatedly applied for the investigation of chloroplast morphology and structural dynamics in higher plants (Pyke and Page 1998, Sarafis 1998, Zheng et al. 2002). Sarafis (1998) observed CLs, by LSM images, in the Angiosperm Ophiopogon nigrescens (Asparagaceae) and in the Anthocerophyta Notothylas sp. (Notothyladaceae), and established a close morphological relation between CLs and stromules. Stromules or stroma-filled tubules are structures constituted of stroma found in green algae and plants, which are involved in molecular transport between chloroplasts and other organelles (Menzel 1994, Hanson and Sattarzadeh 2011).

At the present work, the diameter and length of CLs found in Y. poiteaui var. $(0.47 \pm 0.10 \mu \mathrm{m} / 4.52 \pm 1.0 \mu \mathrm{m})$ and $L$. dendroidea $(0.47 \pm 0.05 \mu \mathrm{m} / 6.6 \pm 2.0 \mu \mathrm{m})$ presented similar measurements from that determined in plant stromules (diameter 0.35-0.85 $\mu \mathrm{m}$ / length up to $220 \mu \mathrm{m}$ ) (Natesan et al. 2005). But, stromules are free of thylakoids (Hanson and Sattarzadeh 2011), while Laurencia CLs have chlorophyll $a$ and perform photosynthesis. Further studies using specific stroma dyes are needed to verify the presence of stromules in Laurencia species.

The LSM images of live cortical cells from Laurencia sensu latu species showed that CLs of each species has its own characteristics. Generally, all of them are lobed, but with a certain kind of idiosyncrasy. For example, L. dendroidea and Y. poiteaui var. CLs are in general undulated varying from thicker / longer to small / thin tubules. Otherwise, the L. translucida CLs are always thin and short like inconspicuous projections. The L. dendroidea and $Y$. 

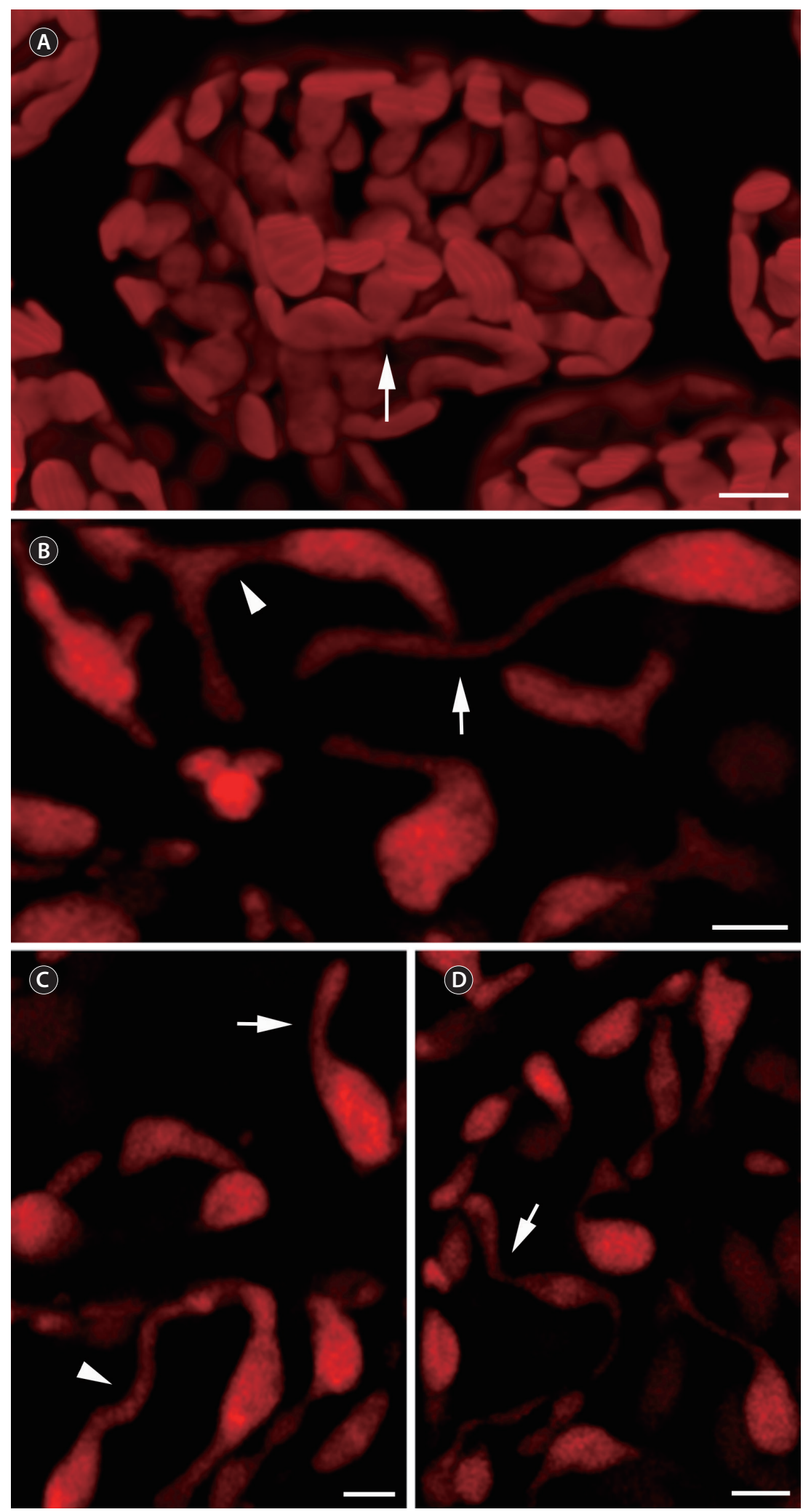

Fig. 2. Choroplast lobes (CLs) in Laurencia. (A) A three-dimensional reconstruction with confocal laser scanning microscopy (LSM) images of fusionned chloroplasts (arrow) in Yuzurua poiteaui var. cortical cells. (B) LSM images of thin undulated (arrow) and thick linear (arrowhead) CL in L. dendroidea cortical cells. (C \& D) Short / unilateral (arrows) and thick / bilateral (arrowheads) CL in L. dendroidea cortical cells. Scale bars represent: A-D, $2 \mu \mathrm{m}$. 

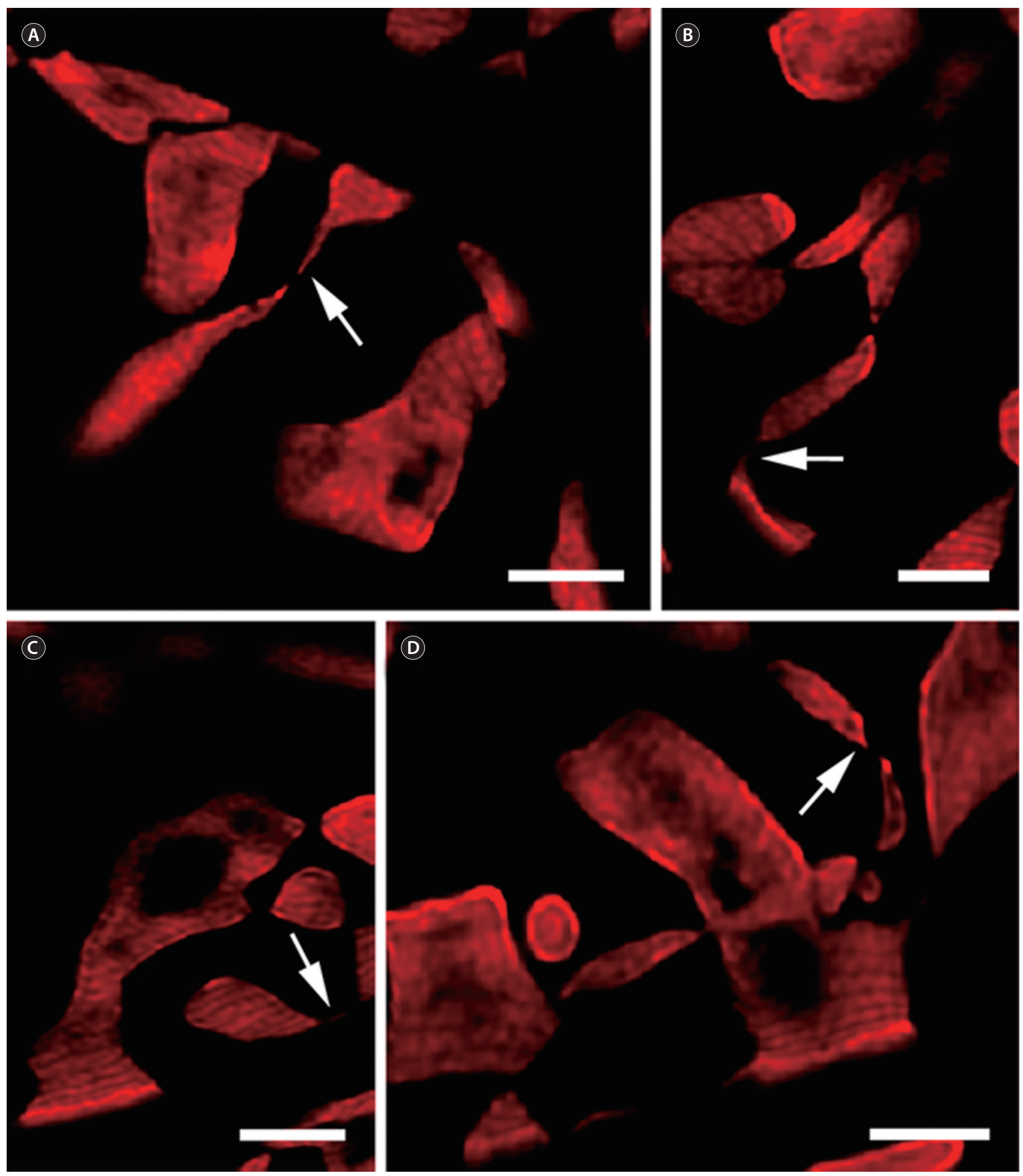

Fig. 3. Choroplast lobes (CLs) in Laurencia translucida cortical cells. (A \& B) Confocal laser scanning microscopy images of thin / unilateral CLs (arrows). (C \& D) CLs always as inconspicuous projections (arrows). Scale bars represent: A-D, $2 \mu \mathrm{m}$. 
poiteaui var. CLs presented higher diameter and length than L. translucida CLs. Based on LSM observations, we suggest that lobes morphology do not have diagnostic value at the generic level. It can have a taxonomic validity only to characterize $L$. translucida species.

From all species of Laurencia complex, until now, only two of them were studied in cellular, ecological and chemical levels, Laurencia dendroidea (Da Gama et al. 2003, Sudatti et al. 2006, Salgado et al. 2008) and Laurencia translucida (Fujii et al. 2011, Paradas 2013). According to Garbary and Gabrielson (1990), the chemotaxonomy of red algae had been hampered by the strong intra-populational variability and by the production of secondary metabolites by thalli parasites or epibionts (Crews and Selover 1986, Da Gama et al. 2014), which in many cases difficult the taxonomic use of halogenated metabolites (Garbary and Gabrielson 1990).

But recently, morphological, molecular and chemical data from Laurencia species have been used to understand the evolution of this group (Fujii et al. 2011). For example, Laurencia dendroidea produces as major metabolites terpenoids with a broad scale of biological activity (e.g., antifouling) and stores it inside CC found in cortical cells (Salgado et al. 2008, Paradas et al. 2010), while $L$. translucida possess specialized translucent cortical cells, which are involved in fatty acids derivatives biosynthesis with biological activity (e.g., antifouling) (Paradas 2013). These works have been showing that specific secondary metabolites are biosynthesized inside algae cells (Salgado et al. 2008, Paradas 2013).

Regarding to CLs data, L. translucida and Y. poiteaui var. / $L$. dendroidea are examples of extremely different chloroplasts shapes. Future studies revealing the nature of Laurencia secondary metabolites allied to new morphological analyses (e.g., CLs or storage structures) should help the understanding of evolution and phylogenetic relationships in Laurencia complex.

In conclusion, this work described for the first time CLs in Laurencia species by using distinct cellular approaches; different chloroplasts morphologies were also observed among Laurencia species, which indicates for a possible taxonomic approach based on morphology of CLs.

\section{ACKNOWLEDGEMENTS}

We thank Dr. Bechara Kachar (NIDCD, NIH, Bethesda, $\mathrm{MD}$ ) for the use of the microscopes, Jennifer Sweatman (FIU, Florida), Pamela Parker (FIU, Florida), and Alex Per- ez (FIU, Florida) for sampling support in the Florida Keys. We also thank Dr. Ricardo da Gama Bahia by the support to include Laurencia species in herbarium from Instituto de Pesquisas Jardim Botânico Rio de Janeiro. The authors are grateful to Coordenação de Aperfeiçoamento de Pessoal de Nível Superior (CAPES) and Conselho Nacional de Desenvolvimento Científico e Tecnológico (CNPq) for financial support. R. C. P., G. M. A. F., and L. T. S. are CNPq research fellows.

\section{REFERENCES}

Abe, T., Kurihara, A., Kawaguchi, S., Terada, R. \& Masuda, M. 2006. Preliminary report on the molecular phylogeny of the Laurencia complex (Rhodomelaceae). Coast. Mar. Sci. 30:209-213.

Abramoff, M. D., Magalhães, P. J. \& Ram, S. J. 2004. Image processing with ImageJ. Biophotonics Int. 11:36-42.

Barnabas, A. D. 1982. Fine structure of the leaf epidermis of Thalassodendron ciliatum (Forsk.) den Hartog. Aquat. Bot. 12:41-55.

Bisalputra, T. \& Bailey, A. 1973. The fine structure of the chloroplast envelope of a red alga, Bangia fusco-purpurea. Protoplasma 76:443-454.

Bouzon, Z. L., Chow, F., Zitta, C. S., Dos Santos, R. W., Ouriques, L. C., Felix, M. R. L., Osorio, L. K. P., Gouveia, C., Martins, R. P., Latini, A., Ramlov, F., Maraschin, M. \& Schmidt, E. C. 2012. Effects of natural radiation, photosynthetically active radiation and artificial ultraviolet radiation-B on the chloroplast organization and metabolism of Porphyra acanthophora var. brasiliensis (Rhodophyta, Bangiales). Microsc. Microanal. 18:1467-1479.

Cole, K. \& Sheath, R. G. 1980. Ultrastructural changes in major organelles during spermatial differentiation in Bangia (Rhodophyta). Protoplasma 102:253-279.

Crews, P. \& Selover, S. J. 1986. Comparison of the sesquiterpenes from the seaweed Laurencia pacifica and its epiphyte Erythrocystis saccata. Phytochemistry 25:18471852.

Da Gama, B. A. P., Pereira, R. C., Soares, A. R., Teixeira, V. L. \& Yoneshigue-Valentin, Y. 2003. Is the mussel test a good indicator of antifouling activity? A comparison between laboratory and field assays. Biofouling 19:161-169.

Da Gama, B. A. P., Plouguerné, E. \& Pereira, R. C. 2014. The antifouling defence mechanisms of marine macroalgae. In Bourgougnon, N. (Ed.) Advances in Botanical Research. Elsevier B.V., Amsterdam, pp. 413-440.

De Oliveira, L. S., Gregoracci, G. B., Silva, G. G. Z., Salgado, L. T., Filho, G. A., Alves-Ferreira, M., Pereira, R. C. \& 
Thompson, F. L. 2012. Transcriptomic analysis of the red seaweed Laurencia dendroidea (Florideophyceae, Rhodophyta) and its microbiome. BMC Genomics 13:487.

De Oliveira, L. S., Tschoeke, D. A., De Oliveira, A. S., Hill, L. J., Paradas, W. C., Salgado, L. T., Thompson, C. C., Pereira, R. C. \& Thompson, F. L. 2015. New insights on the terpenome of the red seaweed Laurencia dendroidea (Florideophyceae, Rhodophyta). Mar. Drugs 13:879-902.

Díaz-Larrea, J., Sentíes, A., Fujii, M. T., Pedroche, F. F. \& Oliveira, M. C. 2007. Molecular evidence for Chondrophycus poiteaui var. gemmiferus comb. et stat. nov. (Ceramiales, Rhodophyta) from the Mexican Caribbean Sea: implications for the taxonomy of the Laurencia complex. Bot. Mar. 50:250-256.

Dos Santos, R. W., Schmidt, E. C., Felix, M. R. L., Polo, L. K., Kreusch, M., Pereira, D. T., Costa, G. B., Simioni, C., Chow, F., Ramlov, F., Maraschin, M. \& Bouzon, Z. L. 2014. Bioabsorption of cadmium, copper and lead by the red macroalga Gelidium floridanum: physiological responses and ultrastructure features. Ecotoxicol. Environ. Saf. 105:80-89.

Feldmann, J. \& Feldmann, G. 1950. Les “corps en cerise” des Laurencia (Rhodomelacées, Ceramiales). C. R. Acad. Sci. Paris Ser. D 266:2393-2396.

Fujii, M. T., Cassano, V., Stein, E. M. \& Carvalho, L. R. 2011. Overview of the taxonomy and of the major secondary metabolites and their biological activities related to human health of the Laurencia complex (Ceramiales, Rhodophyta) from Brazil. Braz. J. Pharmacogn. 21:268-282.

Fujii, M. T., Guimarães, S. M. P. B., Gurgel, C. F. D. \& Fredericq, S. 2006. Characterization and phylogenetic affinities of the red alga Chondrophycus flagelliferus (Rhodomelaceae, Ceramiales) from Brazil on the basis of morphological and molecular evidence. Phycologia 45:432-441.

Garbary, D. J. \& Gabrielson, P. W. 1990. Taxonomy and evolution. In Cole, K. M. \& Sheath, R. G. (Eds.) Biology of the Red Algae. Cambridge University Press, Cambridge, pp. 477-498.

Garbary, D. J. \& Harper, J. T. 1998. A phylogenetic analysis of the Laurencia complex (Rhodomelaceae) of the red algae. Cryptogam. Algol. 19:185-200.

Geitler, L. 1927. Rhodospora sordida, nov. gen. et n. sp., eine neue 'Bangiacee' des Süßwassers. Österr. Bot. Z. 76:2528.

Gillard, J., Devos, V., Huysman, M. J. J., De Veylder, L., D’Hondt, S., Martens, C., Vanormelingen, P., Vannerum, K., Sabbe, K., Chepurnov, V. A., Inzé, D., Vuylsteke, M. \& Vyverman, W. 2008. Physiological and transcriptomic evidence for a close coupling between chloroplast ontogeny and cell cycle progression in the pennate diatom
Seminavis robusta. Plant Physiol. 148:1394-1411.

Gil-Rodríguez, M. C., Sentíes, A., Díaz-Larrea, J., Cassano, V. \& Fujii, M. T. 2009. Laurencia marilzae sp. nov. (Ceramiales, Rhodophyta) from the Canary Islands, Spain, based on morphological and molecular evidence. J. Phycol. 45:264-271.

Gouveia, C., Kreusch, M., Schmidt, E. C., Felix, M. R. L., Osorio, L. K. P., Pereira, D. T., Dos Santos, R., Ouriques, L. C., Martins, R. P., Latini, A., Ramlov, F., Carvalho, T. J. G., Chow, F., Maraschin, M. \& Bouzon, Z. L. 2013. The effects of lead and copper on the cellular architecture and metabolism of the red alga Gracilaria domingensis. Microsc. Microanal. 19:513-524.

Hanson, M. R. \& Sattarzadeh, A. 2011. Stromules: recent insights into a long neglected feature of plastid morphology and function. Plant Physiol. 155:1486-1492.

Johansen, J. R., Fučíková, K., Fitzpatrick, M. H. \& Lowe, R. L. 2005. The red alga genus Rhodospora (Bangiophyceae, Rhodophyta): first report from North America. J. Phycol. 41:1281-1283.

Kachar, B., Parakkal, M., Kurc, M., Zhao, Y. \& Gillespie, P. G. 2000. High-resolution structure of hair-cell tip links. Proc. Natl. Acad. Sci. U. S. A. 97:13336-13341.

Kachar, B. \& Reese, T. S. 1988. The mechanism of cytoplasmic streaming in characean algal cells: sliding of endoplasmic reticulum along actin filaments. J. Cell Biol. 106:1545-1552.

Kikuchi, N. \& Shin, J. -A. 2005. Morphology and life history of Stylonema cornu-cervi Reinsch (Goniotrichales, Rhodophyta) from Japan. Algae 20:37-42.

Kushibiki, A., Yokoyama, A., Iwataki, M., Yokoyama, J., West, J. A. \& Hara, Y. 2012. New unicellular red alga, Bulboplastis apyrenoidosa gen. et sp. nov. (Rhodellophyceae, Rhodophyta) from the mangroves of Japan: phylogenetic and ultrastructural observations. Phycol. Res. 60:114122.

Martin-Lescanne, J., Rousseau, F., De Reviers, B., Payri, C., Couloux, A., Cruaud, C. \& Le Gall, L. 2010. Phylogenetic analyses of the Laurencia complex (Rhodomelaceae, Ceramiales) support recognition of five genera: Chondrophycus, Laurencia, Osmundea, Palisada and Yuzurua stat. nov. Eur. J. Phycol. 45:51-61.

Menzel, D. 1994. An interconnected plastidom in Acetabular$i a$ : implications for the mechanism of chloroplast motility. Protoplasma 179:166-171.

Metti, Y., Millar, A. J. K. \& Steinberg, P. 2015. A new molecular phylogeny of the Laurencia complex (Rhodophyta, Rhodomelaceae) and a review of key morphological characters result in a new genus, Coronaphycus, and a description of C. novus. J. Phycol. 51:929-942. 
Müller, K. M., Lynch, M. D. J. \& Sheath, R. G. 2010. Bangiophytes: from one class to six; where do we go from here? In Seckbach, J. \& Chapman, D. J. (Eds.) Red Algae in the Genomic Age, Cellular Origin, Life in Extreme Habitats and Astrobiology. Springer-Verlag, Berlin, pp. 241-259.

Nam, K. W. 1999. Morphology of Chondrophycus undulate and C. parvipapillata and its implications for the taxonomy of the Laurencia (Ceramiales, Rhodophyta) complex. Eur. J. Phycol. 34:455-468.

Nam, K. W. 2006. Phylogenetic re-evaluation of the Laurencia complex (Rhodophyta) with a description of L. succulenta sp. nov. from Korea. J. Appl. Phycol. 18:679-697.

Nam, K. W., Maggs, C. A. \& Garbary, D. J. 1994. Resurrection of the genus Osmundea with an emendation of the generic delineation of Laurencia (Ceramiales, Rhodophyta). Phycologia 33:384-395.

Nam, K. W., Maggs, C. A., McIvor, L. \& Stanhope, M. J. 2000. Taxonomy and phylogeny of Osmundea (Rhodomelaceae, Rhodophyta) in Atlantic Europe. J. Phycol. 36:759772.

Natesan, S. K. A., Sullivan, J. A. \& Gray, J. C. 2005. Stromules: a characteristic cell-specific feature of plastid morphology. J. Exp. Bot. 56:787-797.

Paradas, W. C. 2013. Mecanismos de armazenamento, biossíntese e liberação de metabólitos secundários em macroalgas vermelhas (Rhodophyta) in Brazil. Ph.D. dissertation, Universidade Federal Fluminense, Niterói, Brazil, 179 pp.

Paradas, W. C., Crespo, T. M., Salgado, L. T., De Andrade, L. R., Soares, A. R., Hellio, C., Paranhos, R. R., Hill, L. J., De Souza, G. M., Kelecom, A. G. A. C., Da Gama, B. A. P., Pereira, R. C. \& Amado-Filho, G. M. 2015. Mevalonosomes: specific vacuoles containing the mevalonate pathway in Plocamium brasiliense cortical cells (Rhodophyta). J. Phycol. 51:225-235.

Paradas, W. C., Salgado, L. T., Sudatti, D. B., Crapez, M. A., Fujii, M. T., Coutinho, R., Pereira, R. C. \& Amado Filho, G. M. 2010. Induction of halogenated vesicle transport in cells of the red seaweed Laurencia obtusa. Biofouling $26: 277-286$

Proctor, M. C. F., Ligrone, R. \& Duckett, J. G. 2007. Desiccation tolerance in the moss Polytrichum formosum: physiological and fine-structural changes during desiccation and recovery. Ann. Bot. 99:75-93.

Pyke, K. A. \& Page, A. M. 1998. Plastid ontogeny during petal development in Arabidopsis. Plant Physiol. 116:797-803.

Reis, V. M., Oliveira, L. S., Passos, R. M. F., Viana, N. B., Mermelstein, C., Sant'Anna, C., Pereira, R. C., Paradas, W. C., Thompson, F. L., Amado-Filho, G. M. \& Salgado, L. T. 2013. Traffic of secondary metabolites to cell surface in the red alga Laurencia dendroidea depends on a twostep transport by the cytoskeleton. PLoS ONE 8:e63929.

Saito, Y. 1967. Studies on Japanese species of Laurencia, with special reference to their comparative morphology. Mem. Fac. Fish. Hokkaido Univ. 15:1-81.

Salgado, L. T., Viana, N. B., Andrade, L. R., Leal, R. N., Da Gama, B. A. P., Attias, M., Pereira, R. C. \& Amado Filho, G. M. 2008. Intra-cellular storage, transport and exocytosis of halogenated compounds in marine red alga Laurencia obtusa. J. Struct. Biol. 162:345-355.

Sarafis, V. 1998. Chloroplasts: a structural approach. J. Plant Physiol. 152:248-264.

Schmidt, E. C., Pereira, B., Dos Santos, R. W., Gouveia, C., Costa, G. B., Faria, G. S. M., Scherner, F., Horta, P. A., Martins, R. P., Latini, A., Ramlov, F., Maraschin, M. \& Bouzon, Z. L. 2012. Responses of the macroalgae Hypnea musciformis after in vitro exposure to UV-B. Aquat. Bot. 100:8-17.

Schottkowski, M., Peters, M., Zhan, Y., Rifai, O., Zhang, Y. \& Zerges, W. 2012. Biogenic membranes of the chloroplast in Chlamydomonas reinhardtii. Proc. Natl. Acad. Sci. U. S. A. 109:19286-19291.

Škaloud, P., Neustupa, J., Radochová, B. \& Kubínová, L. 2005. Confocal microscopy of chloroplast morphology and ontogeny in three strains of Dictyochloropsis (Trebouxiophyceae, Chlorophyta). Phycologia 44:261-269.

Sudatti, D. B., Rodrigues, S. V. \& Pereira, R. C. 2006. Quantitative GC-ECD analysis of halogenated metabolites: determination of surface and within-thallus elatol of Laurencia obtusa. J. Chem. Ecol. 32:835-843.

Suzuki, M., Kurosawa, E. \& Kurata, K. 1987. (E)-Tridecyl2-heptadecenal, an unusual metabolites from the red alga Laurencia species. Bull. Chem. Soc. Jpn. 60:37933794 .

Tischendorf, G., Oesterhelt, C., Hoffmann, S., Girnus, J., Schnarrenberger, C. \& Gross, W. 2007. Ultrastructure and enzyme complement of proplastids from heterotrophically grown cells of the red alga Galdieria sulphuraria. Eur. J. Phycol. 42:243-251.

Wilson, S., West, J., Pickett-Heaps, J., Yokoyama, A. \& Hara, Y. 2002. Chloroplast rotation and morphological plasticity of the unicellular alga Rhodosorus (Rhodophyta, Stylonematales). Phycol. Res. 50:183-191.

Yoon, H. S., Ciniglia, C., Wu, M., Comeron, J. M., Pinto, G., Pollio, A. \& Bhattacharya, D. 2006. Establishment of endolithic populations of extremophilic Cyanidiales (Rhodophyta). BMC Evol. Biol. 6:78.

Young, D. N. 1978. Ultrastructural evidence for a secretory function in the "land cells" of the marine red alga Botryodadia pseudodichotoma (Rhodymeniaceae). Protoplasma 94:109-126. 
Zheng, P., Wetzel, C., Ammar, K., Girard, A. -M. M., Rodermel, S., Thomas, D. R., Ning, L., Callis, J. B., Edwards, G. E. \& Daley, L. 2002. Test of an in vivo method to detect chloroplast division in crop plants. Part II: verification of the phenomenon by germplasm methods and confocal microscopy. Spectroscopy 17:14-18. 
Reproduced with permission of the copyright owner. Further reproduction prohibited without permission. 